\title{
Os estudos etnográficos no Instituto Histórico e Geográfico Brasileiro (1840-1860): história, viagens e questão indígena \\ The ethnographic studies of the Instituto Histórico e Geográfico Brasileiro (1840-1860): history, travels and indigenous question
}

Kaori Kodamal

Resumo: $\bigcirc$ artigo aborda a etnografia do Instituto Histórico e Geográfico Brasileiro (IHGB) em meados do século XIX, dando destaque à produção etnográfica do sócio da instituição, Antônio Gonçalves Dias. Chama a atenção para alguns aspectos que caracterizaram os estudos indígenas do momento: a visão dicotômica entre índios do passado e índios do presente que se desdobrava na percepção dos grupos de origem tupi e os 'tapuias', conhecidos também como não falantes do tupi ou índios do sertão; e a dependência da disciplina etnográfica do campo da história, então em pleno desenvolvimento no IHGB. Tais aspectos, que invariavelmente anunciavam uma perspectiva 'decadentista' sobre os índios, repercutiram nas ações políticas que os envolveram no período e, ao mesmo tempo, impossibilitaram a percepção da imensa variabilidade étnica existente no interior do Brasil, quando os intelectuais da instituição seguiram em viagem às províncias do Norte. Não obstante o anúncio constante do desaparecimento dos índios, algum legado dessa viagem permite entrever a riqueza do material coletado junto àquelas populações, que, sob formas distintas de presença na atualidade, continuam a nos fornecer reflexões sobre a complexidade da formação nacional.

Palavras-chave: Etnografia. Historiografia. Império brasileiro. Índios. Antônio Gonçalves Dias. Instituto Histórico e Geográfico Brasileiro.

Abstract: The article examines the ethnography of the Instituto Histórico e Geográfico Brasileiro (IHGB) in the mid-19th century, highlighting the ethnographic production of its member, Antônio Gonçalves Dias. It emphasizes some of the aspects which characterized the indigenous studies at that moment: the dichotomous image between the Indians of the past and the Indians of the present that echoed in the perception of the Tupi groups and the Tapuia, known as the non-speaking Tupi language groups or the Indians of the hinterland; and the subjection of ethnography to the field of history, as developed in the IHGB. These aspects were related to the theories about the 'decadence' of the Indians and directly affected both the way the Indigenous policies were built and the incapacity of Brazilian intellectuals to assess the ethnic diversity, when some of the IHGB members travelled to the northern provinces of Brazil. Although the Indians extinction was constantly announced, the legacy of this expedition allows glimpsing the richness of the material collected within the indigenous peoples, which continues to challenge in different ways considerations about the complexity of Brazilian national formation.

Keywords: Ethnography. Historiography. Brazilian Empire. Indians. Antônio Gonçalves Dias. Instituto Histórico e Geográfico Brasileiro.

Fundação Oswaldo Cruz. Casa de Oswaldo Cruz. Rio de Janeiro, Rio de Janeiro, Brasil (kaori@fiocruz.br).

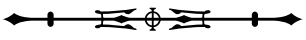




\section{INTRODUÇÃO}

Em conferência realizada na Academia Brasileira de Letras, em 1943, Edgard Roquette-Pinto tematizou o patrono da cadeira número 15 daquela associação, Antônio Gonçalves Dias (1823-1864). O discurso de Roquette-Pinto, intitulado "Gonçalves Dias e os índios", chamava a atenção para os diferentes trabalhos etnográficos do autor da "Canção do Exilio", que completava seu centenário naquele ano. A fala do ex-diretor do Museu Nacional começava com uma menção à própria classificação antropológica sobre seu homenageado, o qual considerava seu primeiro 'mestre' em matéria de etnologia brasiliana: teria sido o poeta, muito provavelmente, um "xantodermo", caracterização que só seria possível averiguar com a medição da largura nasal de Gonçalves Dias - o que era irrealizável, visto que o corpo do poeta se perdeu no naufrágio quando voltava ao Maranhão, em 1864. Em todo o caso, sua origem seria de obscuri et mixti sanguinis (Roquette-Pinto, 1948, p. 83).

Essa afirmação de Roquette-Pinto não parece ser casual. Ela denota que importava pouco a exata classificação racial do poeta frente à produção intelectual de um legítimo brasileiro, fruto da mestiçagem. $O$ fato de Gonçalves Dias ter sido mestiço, filho de um português com uma cafuza, foi um dos aspectos que muitos autores no período destacaram como elemento que lhe fez alcançar uma verdadeira brasilidade em sua obra poética. Lucia Miguel Pereira enfatiza essa característica na biografia "A vida de Gonçalves Dias" (Pereira, 1943). A origem do poeta realçaria a condição peculiar de seu indianismo e de seu romantismo trágico, que foi considerado mais genuíno e menos oficial quando comparado ao de Gonçalves de Magalhães, por exemplo (Cândido, 1993).

No entanto, o que nos interessa no texto de RoquettePinto é certo deslocamento que ele passava a efetivar em sua leitura sobre a obra do poeta. Diferentemente do habitual viés adotado pela crítica literária, que tomava o seu legado lírico, aquela 'brasilidade' de Gonçalves Dias, fosse ou não atestada pela origem mestiça, era contemplada em relação aos seus estudos em etnografia - aspecto que, poderíamos dizer, é pouco lembrado mesmo hoje em dia. Com esse deslocamento, o discurso de Roquette-Pinto lança luzes sobre a distinção das concepções e práticas etnográficas de dois momentos: aquele próprio em que se enunciava a conferência, quando se ampliava o conhecimento de diferentes grupos indígenas pelos 'sertões' (Lima et al., 2008) e aquele do qual se falava!.

A poesia de Gonçalves Dias, notava Roquette-Pinto, privilegiou o tupi, a ponto de ter sido a língua falada por índios Timbira em seu poema "Os Timbiras", quando estes, na verdade, eram 'tapuias', ou índios de 'língua travada'. Assim, declara Roquette-Pinto:

\begin{abstract}
Conscientemente, seguro do que fazia, tomou a liberdade de dar língua Tupi aos seus Timbiras tabupais, parentes, pois, dos Botocudos. Convenhamos que Botocudo - praticando a antropofagia alimentar, a androfagia, como quer o meu ilustre mestre Basilio de Magalhães - não daria ao poeta as possibilidades que uma tribo Tupi - que só praticava a antropofagia ritual, era capaz de oferecer. Um Gê dificilmente seria aquele modelo de nobreza e valentia, pelo menos teoricamente (Roquette-Pinto, 1948, p. 84).
\end{abstract}

De todo modo, continuava o palestrante, essa "licença etnográfica" era menos grave do que a inclusão da palavra "manitô" no poema, quando ela designa um fetiche de origem algonquin, de índios da América do Norte (Roquette-Pinto, 1948).

Roquette-Pinto reiterava as análises feitas por Raimundo Lopes, seu discípulo então já morto, e que deixara em 1933 um trabalho intitulado "Gonçalves Dias e a raça

\footnotetext{
Cabe, talvez, notar que o termo 'etnografia' adotado neste texto deve ser entendido de forma bastante elástica, para dar conta de apropriações distintas que a palavra foi assumindo ao longo do tempo. Como o intuito do artigo é tratar dos 'estudos indígenas' praticados pelos membros do Instituto Histórico nas suas primeiras décadas de existência, assumo que 'etnografia' é termo que se aplica a todos os textos que se referiam aos índios com o intuito de torná-los objeto de um 'conhecimento' mais ou menos formalizado e consubstanciado nos moldes científicos aceitos em seu momento.
}

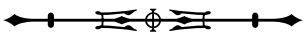


americana", apresentado no Instituto Histórico e Geográfico Brasileiro durante o primeiro Congresso do Instituto PanAmericano de Geografia e História, no IHGB2 (Lopes, 1933). Tanto ele como Raimundo Lopes defenderam que o uso da língua geral - ou do tupi dicionarizado por missionários e falado por bandeirantes - em um poema sobre índios 'tapuias' teria sido uma estilização consciente de Gonçalves Dias. Afinal, os Timbira eram índios da região de Caxias, cidade natal do poeta, e seus escritos deixavam entrever que os considerava tapuias. Ressaltavam os antropólogos que eles pertenciam ao mesmo grupo que os Canela, os Piokojé, Aponejikran, Makamecran (Lopes, 1933; Roquette-Pinto, 1948) e, portanto, ao tronco linguístico modernamente conhecido como Macro-jê, no qual também se incluem os Botocudo. Essa designação do tronco foi feita a partir da atribuição do naturalista alemão Karl Friedrich Philipp von Martius (1794-1868) a diversas línguas em que se tinha a presença do sufixo 'jê'. No entanto, o conhecimento dos grupos Jê, que se esboçava a partir do século XIX por trabalhos de Maximilian zu Wied-Neuwied (1782-1867) e do próprio Martius, se ampliou plenamente somente durante o século $X X$.

A tomada de maior interesse da etnologia pelos grupos não tupis tem início com as expedições realizadas por Karl von den Steinen (1855-1929) e por Paul Ehrenreich (1855-1914) pelo Brasil central, na década de 1880. São esses etnólogos que farão as críticas à 'tupimania' que teria relegado valor secundário aos estudos sobre os 'tapuia' durante grande parte do século XIX, sobrevalorizando os Tupi. Em particular, Steinen e Ehrenreich reveriam as considerações de Martius acerca das línguas indígenas, uma vez que seus trabalhos teriam auxiliado a difundir a ideia da exagerada expansão dos grupos tupi pelo Brasil (Christino e Cruz, 2005). Capistrano de Abreu (1853-1927), seguindo a esteira desses alemães, faria parte da rede internacional de estudos sul-americanísticos de fins do século XIX e início do
XX (Christino, 2007), ao realizar levantamento e pesquisas sobre as línguas dos Bakairi e dos Caxinauá. A própria compreensão do 'tapuia' e da etnografia se modificaria a partir daí, incluindo-se, neste processo, os estudos posteriores de Curt Nimuendajú (1883-1945) e de Robert Lowie (1883-1957), os quais começavam a ser divulgados na década de 1940, quando Roquette-Pinto fazia seu discurso (Cunha, 1993). A limitação do poeta indianista, portanto, seria compreensível, uma vez que ele não conhecera as classificações modernas (Roquette-Pinto, 1948, p. 84).

No seu diálogo com o poema, o discurso evidencia algo que distanciava os lugares de fala do acadêmico em relação aos trabalhos de Gonçalves Dias. Não obstante ser possível encontrar em Roquette-Pinto ainda certa valorização dos tupis - pois lembrava que estes só praticariam a antropofagia ritual -, sua fala marcava e celebrava o próprio caminhar do campo da etnografia como uma ciência, pensando os grupos indígenas a partir de outros referenciais.

Entre um e outro tempo, encontram-se camadas espessas que os separavam: estudos linguísticos, como o de Martius; uma série de viagens aos sertões realizadas por estrangeiros e por brasileiros, como as do próprio Roquette-Pinto (Roquette-Pinto, 2005), de Steinen e de Ehrenreich, de Theodor Koch-Grünberg (1872-1924) e, depois, de Nimuendajú; compilações de dicionários e trabalhos em crítica histórica, como os de Capistrano de Abreu; sem mencionar o próprio papel que veio a assumir a prática etnográfica no conhecimento antropológico (Clifford, 1998; Stocking Jr., 1983).

O que se pretende neste artigo é retomar o contexto da produção etnográfica de Gonçalves Dias e da instituição que o agregou, o IHGB, destacando sua estreita relação com a formação do campo disciplinar da história no século XIX e algumas de suas principais características. Ao mesmo tempo, procura-se abordar certos aspectos da viagem de

\footnotetext{
2 Sobre a formação do Instituto Pan-Americano de Geografia e História, cuja sede foi estabelecida no México, ver a menção feita em
} Guimarães (1997).

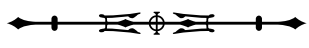


Gonçalves Dias no contexto da Comissão Científica de Exploração, que começou em 1859, e sua ida posterior à província do Amazonas.

\section{TUPIS E TAPUIAS: FORMAS DO MESMO?}

A sensação de artificialidade em "Os Timbiras", percebida por leitores do século XX como Roquette-Pinto e Lopes, também era fruto das mudanças na forma de se pensar os índios naquele século em relação aos meados do XIX. $O$ conhecimento das especificidades étnicas e linguísticas dos povos indígenas tendeu a se adensar conforme novos estudos resultantes de viagens eram divulgados, mas também conforme a intelectualidade brasileira se voltava para a complexidade dos sertões (Amado, 1995; Oliveira, 1998; Lima, 1999) e despertava uma nova atenção pelo interior do país, num movimento que se situa de fins do século XIX e se estende até a fundação de Brasilia. Podese dizer que, não obstante alguns esforços dos letrados do Instituto em levantar dados sobre as diversas 'nações' indígenas, como então se dizia, a produção etnográfica entre 1840 e 1860 pouco se interessou pela diversidade étnica em si. O historiador Francisco Adolfo de Varnhagen (1816-1878) não via nos 'tapuias' mais do que 'parentes' desafetos de um mesmo grupo de origem: os tupis. Quando escreveu 'L'Origine Touranienne des Américains Tupis-Caribes et des Anciens Egyptiens", de 1876, seu intuito foi o de provar que os tupis e os caraíbas eram descendentes comuns dos cários da Antiguidade, não porque tivesse interesse nos aspectos linguísticos e culturais em si mesmos, mas porque a evidência de uma origem dos tupis no mundo antigo permitia reforçar sua ideia de que os índios do Brasil eram simplesmente 'povos invasores', como depois teriam sido os europeus (Cezar, 2008).

A variabilidade das línguas e dos povos era, no geral, mal vista. Martius considerava que a diversidade das línguas que encontrara entre os grupos não tupi era a própria evidência de sua decadência e, mesmo, uma espécie de castigo divino, a exemplo das línguas babélicas da Bíblia (Martius, 1863). Perspectiva bastante distinta da de Varnhagen pode ser encontrada em Capistrano de Abreu, o qual, além da 'simpatia' que mantinha para com os índios, se dedicou a incorporar os estudos linguísticos ao seu projeto pessoal de escrita histórica (Amoroso, 1996; Gontijo, 2009).

Uma ideia corrente no século XIX, e que aparecia em periódicos como a revista portuguesa "Panorama", de grande circulação entre os letrados brasileiros, era a de que os grupos indígenas do Brasil poderiam ser divididos em dois principais: tupis e tapuias. Assim os descrevia um artigo de "Panorama" republicado na revista do IHGB em 1845:

\begin{abstract}
Em dois grupos se podem estes [os índios] commodamente dividir. $\bigcirc 1^{\circ}$. comprehende todas aquellas nações, ou raças de gentios indígenas, que fallam com pouca discrepância a mesma língua geral e commum, a que por isso os europeus chamaram língua brasílica. Estes pela maior parte habitavam o litoral no tempo da conquista. - No $2^{\circ}$. entram os que vivendo quase todos mais para o sertão têem entre si línguas e costumes differentes (Artigo..., 1845, p. 499).
\end{abstract}

Tal perspectiva binária e de oposição entre os dois grupos no século XIX prevaleceu em continuidade com a percepção formada pelos colonizadores dos séculos XVI e XVII em relação aos índios do sertão, grupos não tupi cujas línguas eram desconhecidas. A visão bipolar entre o tupi e o tapuia sintetizou a própria lógica da etnografia praticada em meados do século XIX, em particular, aquela que se estabeleceu no Instituto Histórico e Geográfico Brasileiro. É essa bipolaridade, como ressaltaram Cunha (1992a) e Monteiro (1996, 2001), que justifica tanto os estudos sobre o passado indígena quanto a ação pragmática das políticas sobre os povos indígenas coetâneos aos estudos etnográficos da instituição.

De um lado, enaltece-se o tupi por seu legado na formação nacional. As alianças coloniais entre portugueses e povos de origem tupi relatadas em textos de cronistas e de missionários, o estabelecimento de uma gramática tupi e os casamentos interétnicos durante o período colonial, como o de Diogo Álvares, o Caramuru, são elementos que fortaleceram a percepção positiva daqueles grupos

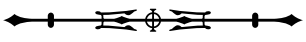


aos membros do instituto quando estes se empenhavam em formar as bases para uma escrita da história do Brasil (Amado, 2000). Ora, para aqueles homens, a língua tupi, ainda que artificialmente dicionarizada pelos missionários coloniais, era instrumento fundamental para a vinculação entre o 'nativismo' e a afirmação nacional. Não só porque os vocábulos tupis eram o que havia de registro no qual poderiam embasar qualquer conhecimento sobre os indígenas dos tempos coloniais, como também porque a forma escrita e a obediência a uma gramática eram o vínculo possível entre um passado 'americano' e a tradição europeia, tão fundamental para garantir as bases civilizatórias da nação em construção.

Esta continuidade entre o movimento literário romântico, que tomou conta do cenário no Brasil pósindependência, e o interesse pela história dos membros do IHGB reflete-se, assim, claramente, nos chamados 'estudos etnográficos' desse momento. Gonçalves Dias, por exemplo, em seu escrito "Brasil e Oceania", asseverava que a língua tupi "tinha uma gramática que pelo bom ordenado de cada uma de suas partes mereceu de ser comparada à grega e à latina" (Gonçalves Dias, 1867, p. 265). Também procurou notar palavras de etimologia tupi e editou o "Dicionário da língua tupi”, em 1857 (Gonçalves Dias, 1998).

Por outro lado, denigre-se o Botocudo ou o índio tapuia ainda 'embrenhado' no interior do país em meados do século XIX. Os Botocudo dos rios Mucuri e Doce eram os índios 'bravos' que, naquele momento, atravancavam os projetos de colonização na região. Contra eles, foi declarada a 'guerra justa' ainda no período de D. João VI, não obstante essa atitude fosse anacrônica se observadas as leis indígenas do século anterior (Cunha, 1992a). Como lembrou Monteiro (1996, p. 15), o Botocudo seria a imagem do índio contemporâneo, "integrante das "hordas selvagens' que erravam pelos sertões incultos" e que contrastava com o "índio histórico, matriz da nacionalidade, tupi por excelência". Falantes de uma língua "gutural", na opinião de Varnhagen (1842), dever-se-ia lançar mão da força sobre estes índios, justificando, sem rodeios, as bandeiras e sua escravização, ainda que dita temporária.

Mesmo que os membros do Instituto Histórico em geral não defendessem os meios violentos de dizimação dos índios, sustentavam que sua presença em territórios recém-abertos à exploração era um entrave para a colonização daquelas áreas. O sócio fundador do IHGB, José Joaquim Machado de Oliveira, quando fora presidente da província do Espírito Santo, afirmava em relatório de 1841 que, não obstante ser "propenso por índole" a querer trazer a "civilização" e "educação social" aos índios, cria que, em seu "estado normal", eles eram nocivos ao território que habitavam (Machado de Oliveira, 1841, p. 43).

Os Botocudo simbolizaram a negatividade do tapuia, o que provavelmente dificultava sua representação como heróis na poesia e literatura romântica (Morel, 2008)3. $\mathrm{Na}$ época de Roquette-Pinto, ainda prevaleceria essa valorização, como é perceptível em seu comentário em relação a "Os Timbiras", sobre os rituais antropofágicos justificáveis dos tupi frente aos não tupi. A valorização do épico pelos indianistas da primeira fase (Sussekind, 1994) compunha a imagem dos índios heróicos, que não era reconhecida nas descrições dos índios 'bravos' ou semibárbaros ainda existentes nos sertões. Estes e seu processo de destribalização não foram contemplados explicitamente pela literatura até fins do século XIX (Treece, 2008, p. 110). Também constituiu mais exceção do que regra a presença de textos na Revista do IHGB que tratavam de índios contemporâneos, como o botocudo Guido Pokrane, que usava sapatos e se tornou chefe dos

\footnotetext{
3 No entanto, é preciso salientar que o próprio desconhecimento sobre as origens de certas etnias gerava certa confusão na representação dos grupos. Um exemplo é Peri, do romance de José de Alencar. Peri, apesar de ser herói de "O Guarani", não é um índio tupi-guarani; ele é goitacá, que, como destaca Treece (2008, p. 253), assim como os aimorés, não era nativo da região que serve de cenário ao romance. A origem dos goitacás só será notada posteriormente, por Capistrano de Abreu, como índios guaianases (Guayanás ou, atualmente, Kaingang) (Abreu, 1989) e que seriam tapuias, contestando a historiografia paulista que pretendia celebrar sua suposta origem tupi (Amoroso, 1996).
}

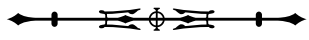


índios do aldeamento dirigido pelo francês Guido Marlière (França, 1855).

Na verdade, é possível observar uma concomitância entre a perspectiva do indianismo romântico e as políticas indigenistas do Império. Como analisa Treece (2008, p. 110), a produção literária indianista que retratou de preferência os índios dos relatos quinhentistas para falar da tragédia da colonização não foi um mero "evasionismo" alheio à situação dos índios do presente. A ênfase na ideia do exílio comum em poesias gonçalvianas era derivada diretamente da consciência dos intelectuais da impossibilidade de efetiva integração dos indígenas. Assim, segundo o autor:

Para os intelectuais que participaram desse debate, muitos deles figuras literárias proeminentes, havia somente duas alternativas - o extermínio ou a integração -, a primeira encapsulada pela política colonial opressora de Portugal, da qual o Brasil agora se achava supostamente livre como Estado-nação independente, ao passo que a segunda refletia a ideologia conciliatória da unidade nacional e social que viria a dominar o Segundo Reinado. Entre essas alternativas não poderia haver nenhuma posição intermediária que questionasse o valor da assimilação na sociedade branca da perspectiva da integridade e identidade cultural do índio ou que denunciasse o caráter predatório da economia imperial para seus elementos marginalizados (Treece, 2008, p. 111).

Se, por um lado, os debates referentes aos índios, que oscilaram entre o extermínio e a assimilação, estabeleceram um lugar discursivo para eles na história por meio dos estudos etnográficos, por outro, conduziram ao próprio processo de 'invisibilização' dos grupos indígenas durante o século XIX. Esse processo está associado ao movimento de busca de expansão de ações civilizatórias por parte do Estado, por meio de políticas específicas criadas neste contexto. Como bem observou Almeida (2009, p. 210), a invisibilização dos grupos indígenas que se firmou como processo não só na experiência brasileira, mas em diferentes partes da América Latina, era também derivada dos ideais de igualdade e de cidadania que não comportavam identidades particulares étnicas, indígenas. Um exemplo concreto que evidencia essa invisibilização do ponto de vista das leis é como foi interpretado e conduzido o Regulamento das Missões de 1845. Embora o Regulamento procurasse estabelecer o direito à terra dos indígenas por meio das missões, ao longo do tempo, estas não estavam garantidas em sua integridade territorial. Elas acabavam sendo dissolvidas, tornando-se constantemente marcadas por uma noção de transitoriedade que se estendia para a caracterização dos próprios índios: estes deveriam, com o passar do tempo, ser "confundidos com a massa da população", como diziam muitas das resoluções e leis posteriores ao Regulamento de 1845 (Cunha, 1992b). É este aparente paradoxo que possibilitou a entrada dos índios na história nacional engendrada durante o Oitocentos. A etnografia indígena era justificada à medida que seu objeto estava em vias de se extinguir. Ao mesmo tempo em que os membros do instituto pretendiam coletar informações sobre os indígenas, de preferência preservados do contato com a civilização, procuraram justificar esses estudos como instrumento útil para a incorporação dos 'índios bravos' pela sociedade imperial, amainando sua 'hostilidade' em relação à mesma e eliminando seus caracteres distintivos.

O ponto crucial que formula essa etnografia é a relação que então se fundamenta entre esse saber e a história, no qual o discurso sobre o 'outro' passa a ser o reflexo invertido da civilização. Se, desde os descobrimentos, é possível afirmar que o 'selvagem' trafegou por diferentes discursos europeus como uma categoria à parte que se impunha na reflexão sobre o tempo, situando-se entre os 'antigos' e os 'modernos' (Hartog, 2005), no momento em que se formava o conhecimento histórico no Brasil do século XIX, a busca da inclusão dos índios em um discurso histórico nacional exortava o desaparecimento de sua própria natureza distintiva. Dessa forma, nenhum dos seus traços no presente os reconhecia como portadores de uma alteridade positiva: os índios contemporâneos eram somente as cinzas de 'raças' do passado e já descaracterizados de sua primitiva existência. Essa quase 
impossibilidade de reconhecimento entre o 'passado e o futuro' indígena, para utilizar o título de uma conferência de Martius, está expressa na leitura decadentista presente em grande parte da etnografia daquele momento.

Relatos como o que escreveu Teófilo Otoni durante suas excursões pelo vale do rio Mucuri reproduzem essa visão dos índios do presente. Otoni tinha a intenção de estabelecer uma colônia na região e travou contatos com os índios botocudos. Para ele, apesar dos muitos indícios, eles não poderiam ser os descendentes dos famosos Aimoré:

Nas feições características dos botocudos eu encontro quanto de mal dizem os historiadores dos aimorés. Mas essa barbaridade, essa estupidez, essa inaptidão para civilizar-se que admito no botocudo não a posso admitir nos aimorés, e seus confederados (Otoni, 2002, p. 60).

A força e a valentia, as quais cria serem características daqueles históricos índios que um dia expulsaram os colonizadores de Porto Seguro, não serviam para qualificar os índios com os quais se defrontava.

A imagem criada sobre os índios ainda existentes - fossem eles 'bravos' ou semi-integrados ao mundo dos brancos - era a de sua decadência civilizatória. Para Gonçalves Dias e grande parte dos intelectuais contemporâneos a ele, mais do que representativos de um estado de natureza, os índios do seu presente eram a prova de que sua civilização teria sido mais briosa no passado. Essa visão sobre a 'decadência' dos 'primitivos habitantes' do continente americano era, em grande parte, pregada por naturalistas, literatos e homens de ciência que refletiam sobre os efeitos da civilização ocidental nas populações não europeias.

Entretanto, há que se dizer que os posicionamentos frente ao fato da então 'evidente' decadência poderiam ser distintos: enquanto que para Martius os sinais da dispersão linguística e da perda de um mais alto grau cultural dos índios deveriam ser atribuídos à própria natureza do desenvolvimento de suas sociedades e não às ações da civilização europeia, que só teria acelerado aquele processo (Martius, 1904; Lisboa, 1997), para Gonçalves Dias, por exemplo, tais sociedades indígenas não teriam decaído tanto assim. O poeta estaria mais afinado com Ferdinand Denis e Chateaubriand, que criam no papel deletério que a colonização teria exercido sobre o estado dos indígenas americanos. Quanto a este julgamento, Denis reproduziria as palavras do romântico Chateaubriand, que visitara a América do Norte no início do século XIX:

\begin{abstract}
L'Indien n'était pas sauvage; la civilisation européenne n'a point agi sur le pur état de nature, elle a agi sur la civilization commençante. Si elle n'eût rien rencontré, elle eût créé quelque chose; mais elle a trouvé des moeurs et les a détruites, parce qu'elle était plus forte e qu'elle n'a pas cru devoir se mêler à ces moeurs (Chateaubriand apud Denis, 1838, p. 33).
\end{abstract}

A leitura 'decadentista' sobre os índios brasileiros é própria do saber etnográfico que seria formulado no IHGB durante o século XIX e estava intimamente vinculada ao engendramento do campo historiográfico no Brasil do período.

\section{O INSTITUTO HISTÓRICO E GEOGRÁFICO BRASILEIRO: A PRODUÇÃO DO CONHECIMENTO HISTÓRICO E O DEBATE ACERCA DOS ÍNDIOS}

Bem conhecido é o papel do Instituto Histórico e Geográfico Brasileiro na produção de conhecimento histórico e científico durante o século XIX (Figueirôa, 1993). Ao ser concebido por personagens do cenário político do Regresso conservador e de tendência liberal-conservadora (Wehling, 1983; Guimarães, 1995, entre outros), ele se funda como instituição criadora e polarizadora do discurso historiográfico no Império do Brasil. Criadora porque a instituição nasceu assumindo a missão de ligar o passado colonial ao futuro da nação imperial, ao 'coligir e metodizar' os documentos do vasto Império do Brasil, como diziam os estatutos de 1839. Polarizadora porque seria o Instituto, por meio de procedimentos específicos, como a legitimação de seus pares - escolhendo seus 
membros como sócios-correspondentes, outorgando medalhas ou lançando pareceres -, e como a eleição e a seleção de temas de estudo, a instância referida como o lugar do saber acadêmico no país ${ }^{4}$.

É no seio dessa instituição que se cria o espaço discursivo da etnografia no Segundo Reinado. O interesse pelos estudos etnográficos dentro da instituição é perceptível desde os primeiros anos de sua fundação. Os debates conduzidos pelo secretário-perpétuo Januário da Cunha Barbosa (1780-1846) nas primeiras reuniões do Instituto para discutir quais seriam as épocas da história do Brasil levaram à discussão sobre o tema dos índios, os quais fariam parte de uma primeira época (Cunha Matos, 1863, p. 129). Proposições para que os sócios da instituição respondessem sobre a forma de 'civilização' dos índios e sobre qual teriam sido os efeitos da escravidão africana sobre ela foram lançadas por Cunha Barbosa (1908 [1839], 1916 [1840]). A tematização do índio ainda ganhava notoriedade com a monografia escrita por Martius, intitulada "Como se deve escrever a história do Brasil", ganhadora do prêmio proposto por Januário da Cunha Barbosa em 1840 para quem oferecesse o melhor plano para se escrever a história antiga e moderna do país (Rodrigues, 1978, p. 130). Como analisa Cezar (2003, p. 182-183), a dissertação de Martius traria uma orientação mais científica e explícita sobre a organização temática da história do Brasil, situando os índios em seu começo. Apesar dos debates inicialmente travados no instituto, não era evidente, naquele momento, que os indígenas deveriam ser tratados nos primeiros capítulos da história do país. Provas dessa falta de consenso seriam obras como a de Rocha Pita, no século XVIII, e a primeira edição da "História Geral do Brasil", de Varnhagen.

No IHGB, uma seção conjunta de Arqueologia e de Etnografia encontra-se formalizada nos "Novos Estatutos do Instituto Histórico e Geográfico", de 18515. Entretanto, sua existência é anterior a eles. Desde as discussões para a revisão dos estatutos, em 1847, já estava formada uma Comissão de Arqueologia e Etnografia Indígena, cujos integrantes inicialmente eram Francisco Freire Alemão, José Joaquim Machado de Oliveira e Joaquim Caetano da Silva (178 ${ }^{a}$ Sessão, 1847). As atividades ligadas a essa comissão podem ser detectadas na proposta encaminhada por Freire Alemão aos membros do Instituto, em 14 de outubro de 1847, na qual pedia informações sobre as tribos indígenas que habitavam as diferentes províncias "no tempo em que o país foi conquistado". Outras informações ainda eram requisitadas: "Quais foram [os grupos] extintos; quais emigraram e para onde; e enfim quais existem ainda e em que estado"6.

A estas perguntas, incluíam-se outras solicitadas por Freire Alemão relativas à flora e fauna locais: "Qual a parte da Província que era já nesses tempos desprovida de matas, quais são os campos nativos, e qual o terreno coberto de florestas virgens; onde estas têm sido destruídas, e onde se conservam e quais as madeiras preciosas de que mais abundavam, e enfim que qualidade de animais as povoavam?"7. As questões colocadas pelo botânico nos remetem ao problema da passagem do tempo, do processo histórico sofrido desde o descobrimento, tanto pelas populações indígenas como pela natureza que existia anteriormente à "conquista", como chama. Com elas, igualmente Freire Alemão trazia

4 Um exemplo das ações do Instituto no sentido de buscar referendar certos encaminhamentos de um modelo de história pode ser visto na polêmica da instituição com o historiador Abreu e Lima a respeito de sua obra "Compêndio da História do Brasil" (Mattos, 2007, p. 178).

5 Os "Novos Estatutos do Instituto Histórico", impressos em 1851, ampliavam o número de comissões permanentes de quatro para dez, incluindo uma comissão separada de "arqueologia, etnografia e línguas indígenas" (ver Novos Estatudos do Instituto Histórico e Geográfico Brasileiro, 1851).

6 Propostas de Francisco Freire Allemão: pedir aos Presidentes das Províncias Informações sobre Tribos Indígenas e Florestas [1847?]. IHGB, Lata 574, pasta 12.

7 Propostas de Francisco Freire Allemão: pedir aos Presidentes das Províncias Informações sobre Tribos Indígenas e Florestas [1847?]. IHGB, Lata 574, pasta 12.

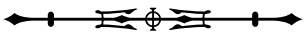


a dimensão histórica dos efeitos da ação colonizadora, como eixo importante para as investigações científicas no Instituto. A partir do que foi dito, verifica-se que a etnografia - aqui entendida como o conjunto de textos dispersos sobre as populações indígenas, produzidos ou comentados pelos literatos e agentes letrados do Império - tinha uma relação de subordinação com a disciplina histórica. A etnografia, então, tanto é um saber auxiliar da história como ela mesma, em sua inteligibilidade, é derivada dos pressupostos do conhecimento histórico que ora se desenvolvia.

As recentes contribuições na historiografia têm procurado inquirir a formação do conhecimento histórico no Instituto Histórico (Guimarães, 2003) e as características da produção historiográfica do período (Wehling, 1983, Guimarães, 1988, 2000; Guimarães, 1995; Cezar, 2004; Oliveira, 2009; Turin, 2009, entre outros). São estes trabalhos que nos permitem avaliar melhor o interesse da instituição pelos assuntos indígenas e o desenvolvimento do campo de conhecimento etnográfico em meados do século XIX. A reflexão sobre os 'selvagens', entendidos como conceito que se posiciona no tempo, foi realizada por diferentes letrados no Império, implicando a criação de visões específicas sobre a historicidade dos habitantes primitivos do território brasileiro (Turin, 2009).

A incorporação das populações indígenas como parte do debate sobre a escrita histórica oitocentista implicou uma mudança de percepção sobre aqueles grupos, que, se antes eram vistos em suas seculares relações de conflitos e alianças com os colonizadores, passavam a ser transpostos a um "regime de historicidade" comum, para utilizar a expressão de François Hartog (2003), e transformados em fontes para a história. Nesse sentido, é emblemática uma frase de Varnhagen em sua "História Geral do Brasil", na qual dizia que dos povos na infância, como eram os índios, "não há história: há só etnografia" (Varnhagen, 1979, p. 38). Ela significa justamente que a inclusão na história do Brasil dos "povos sem história" só poderia ser realizada através daquele saber também em formação.
É esse movimento que vemos no interesse de Francisco Adolfo de Varnhagen, por exemplo, em promover os estudos das línguas indígenas, em 1840, malgrado sua posição avessa aos que defendiam o índio como parte da representação nacional, como era o caso de Gonçalves Dias e de Gonçalves de Magalhães. Ainda que as polêmicas sobre o papel dos indígenas perante a nacionalidade vigorassem entre os letrados brasileiros (Oliveira, 2000; Puntoni, 2003) do período, é importante perceber que a discussão, próíndio ou não, era uma amostra da importância em pensar aqueles grupos sob o ponto de vista histórico.

A relação entre etnografia e história, no Brasil, engendrava-se, assim, no momento em que, com a fundação do Instituto Histórico e Geográfico Brasileiro, se começava a refletir sobre quais seriam os critérios e métodos para se escrever a 'História Pátria'. Os textos escritos nos primeiros anos do instituto, como os de Raimundo José da Cunha Matos, apontam a necessidade de se reunir documentos sobre a "obscura" e antiga história indígena (Cunha Matos, 1863). A "operação historiográfica" (Certeau, 1982) do instituto transforma os relatos de viajantes e cronistas, as descrições sobre os índios nas explorações realizadas pelo Estado português e os relatórios de presidentes das províncias de onde se poderiam obter informações acerca dos diferentes grupos indígenas existentes em fontes para a produção de uma escrita histórica - etapa fundamental na constituição deste saber nos Oitocentos (Guimarães, 2007).

\section{AS ESCRITAS SOBRE OS ÍNDIOS E SEUS USOS}

$O$ destaque que a questão indígena ganhou nas primeiras gerações do Instituto Histórico em seu aporte à história ocorre concomitantemente com as ações civilizatórias do Estado imperial, por meio das políticas indigenistas, em nível mais amplo. Há uma confluência da reflexão do papel e do 'lugar' dos índios em uma história do Brasil, com as formas particulares com que o Estado imperial e seus agentes exerceram a difusão de valores culturais e ações políticas específicas frente à sociedade, no intento de atingir a formação do povo deste mesmo Império

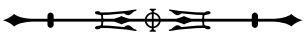


(Mattos, 1994, p. 238, passim). Os textos etnográficos não deixaram de salientar muitas vezes o caráter pragmático da etnografia então praticada: de um lado, as fontes atestam o lugar discursivo sobre os índios como parte do passado nacional, de outro, tratam de conferir um fim útil, como na tradição ilustrada luso-brasileira (Dias, 1968), no qual este conhecimento deveria servir como instrumento de reflexão sobre a 'catequese e civilização' dos índios habitantes do território do Império. É assim que podemos entender, por exemplo, a premiação dada pelo IHGB ao trabalho de Joaquim Norberto Souza e Silva, em 1852, "Memoria historica e documentada das aldêas de indios da Provincia do Rio de Janeiro" (Souza e Silva, 1973).

Quando, em 1859, a Comissão Científica de Exploração - a primeira expedição realizada somente por integrantes brasileiros e patrocinada pelo governo imperial - foi ao Ceará investigar a província, lembrou-se na instrução dos trabalhos que era preciso conhecer, ao lado dos aspectos físicos e dos costumes, "qual a opinião que eles nos têm, quais suas queixas de receios fundamentais" para que fosse possível "chamar à indústria tantos braços perdidos e diminuir o número de inimigos internos" (apud Braga, 1962, p. 208). A frase era de ninguém menos do que do ministro do Império, Luis Pedreira do Couto Ferraz, o que reitera para nós a importância atribuída aos fins pragmáticos do conhecimento sobre os índios pelos próprios dirigentes do Império.

A perspectiva de que havia sobre o território do Império do Brasil 'inimigos internos' a serem reduzidos nos remete a algumas das continuidades que os textos etnográficos do período manteriam com a visão passada e colonial, de necessidade de subjugar outras 'nações' presentes no domínio português. Trata-se aqui, portanto, de considerar a maneira como certo legado administrativo e discursivo sobre as populações dominadas, herdado por agentes do Estado desde a independência, sofreria mudanças ao longo do tempo (Kodama, 2009a). Essas mudanças ocorreriam à medida que o antigo território do Império luso deveria se adequar em uma 'nação', na sua compreensão moderna, isto é, como um Estado reportado a um 'povo' que se queria étnica e historicamente homogeneizado. Ou, como nas palavras de Ilmar Mattos, o percurso que vai do Império do Brasil ao Império do Brasil. Este processo implicou, como na análise do referido autor, uma "expansão para dentro" efetivada pelo Estado e por seus agentes, transformando os referenciais anteriores de um império, cujas fronteiras móveis passam a ser delimitadas pelo espaço nacional (Mattos, 2005).

Em meio a esse processo é que o Estado independente deveria abarcar as diferentes 'nações' existentes em seu território, para subsumi-las dentro do novo corpo da nação brasileira: o Império do Brasil. Essas 'nações' outras, formadas em grande parte por 'índios bravos' e estranhas à sociedade imperial que se formava, requeriam ser controladas e ordenadas por meio de ações policiais e leis criadas no processo de expansão "para dentro" daquele mesmo império (Mattos, 2004). Ao mesmo tempo, o movimento não seria uma retomada do modelo colonial anterior e aplicado a uma nova situação. O próprio teor dos discursos de letrados e de políticos se distanciava dos meios de extermínio praticados no período colonial pela 'guerra justa', e que ainda eram ecoados em diversos pontos dos sertões no século XIX. Essa tônica contra o uso da força, bem como a importância da 'catequese', ainda que mediada pelo Estado, aparece diversas vezes nos debates do IHGB, refletindo o que se colocava no Regulamento das Missões, o qual instituía a presença do missionário nos assentamentos estabelecidos pelo governo imperial.

Um texto de Joaquim José Machado de Oliveira explicita bastante este posicionamento dos sócios em relação à crítica tanto às práticas coloniais de promoção da 'guerra justa' quanto à ingerência dos assuntos indígenas pela Igreja. Não obstante os membros do instituto defenderem a catequese como meio de chamar à civilização os 'índios bravos', não deixavam de salientar a fundamental participação do Estado nesta questão. Machado de Oliveira, que já tinha sido presidente de província de Santa Catarina e do Espírito Santo, lembrava esse aspecto em sua memória sobre os Kayapó, citando o conde Auguste de Straten-Ponthoz: 
meado do século 19 abriu para a América do Sul uma nova era. $O$ catolicismo já não se interpõe como único medianeiro entre os selvagens da raça índia, e os conquistadores europeus: está-se hoje em presença das populações que hão sacudido o regime colonial, e estão no gozo de instituições cujo princípio é chamar à governação do Estado todas as categorias da população.

A segurança e a prosperidade do futuro dos novos Estados independentes consistem na harmonia e justa aplicação destes dous elementos (StratenPonthoz apud Machado de Oliveira, 1973a, p. 523).

A construção do Estado imperial implicava a formação de um discurso histórico singularizador e que igualmente criava descontinuidades nos conceitos anteriores e antigos, como 'civilização', 'nação', 'pátria' (Araújo, 2008).

A etnografia como um campo de estudos de interesse para os letrados surge justamente no decurso das transformações que produzem novas compreensões para tais conceitos, em particular, o de nação. Dessa maneira, não é novidade dizer que a mobilização acerca do índio em meio aos homens de letras e nos debates políticos tinha muito que ver com a discussão sobre a formação do povo. O silêncio sobre o elemento africano era em si parte do problema posto para os letrados em pensar a composição racial da nação. E, diga-se também, que era reflexo de uma sociedade que ainda pouco se distanciava dos valores escravistas que a fundamentavam. Num contexto em que se tinha a perspectiva futura de abolição do trabalho escravo, e em que a questão da colonização por meio da imigração europeia não estava completamente resolvida, a importância em se investir na mão de obra indígena ainda era argumento plausível para certos estadistas e, pode-se acrescentar, para os membros do Instituto Histórico. Esta defesa das políticas indigenistas que se verifica nos letrados do IHGB, como Gonçalves Dias, Machado de Oliveira e Gonçalves de Magalhães, ainda manteve certo fôlego durante algum tempo, encontrando defensores no último quartel do século XIX, como Couto de Magalhães, e mesmo depois.

\section{VIAGENS DO INSTITUTO: GONÇALVES DIAS NA AMAZÔNIA}

Os estudos etnográficos do Instituto Histórico basearam-se, principalmente, em relatórios administrativos sobre aldeias de índios, além de relatos de cronistas e de viajantes. Textos produzidos por membros como Joaquim Norberto Souza e Silva (1973), José Inácio Acioli de Cerqueira e Silva (1849) ou Antônio Gonçalves Dias (1867) podem ser vistos como exemplos desses estudos. Outros textos reproduzidos na revista do Instituto eram os próprios relatórios de presidentes de província ou trechos de diários de campo, como o relato do já citado Machado de Oliveira sobre a celebração da Paixão de Cristo entre os guaranis, em Alegrete, na província de São Pedro (Machado de Oliveira, 1973b). Não obstante esses escritos serem heterogêneos em sua natureza, um aspecto que se pode salientar é a importância da autópsia, na qual a produção do que é verídico legitima-se pelo testemunho ocular (Hartog, 2001), tecendo, assim, o paralelo com o campo da história (Cezar, 2005, p. 28). Da mesma forma que para a disciplina histórica que ganhava foros de conhecimento científico no século XIX, para a etnografia, era importante que os relatos, quer de viajantes, quer de administradores que tivessem conhecido e visto a localidade, fossem transformados em 'documentos', passo fundamental para o processo de cientifização dos saberes histórico e etnográfico.

É devido à credibilidade dada àquele que vê, que os relatos de viajantes, tanto do período colonial como dos tempos modernos, ganhavam centralidade para os trabalhos etnográficos ${ }^{8}$. Mas a base de um conhecimento científico fundamentado no testemunho ocular ainda não implicava a necessidade da observação direta do

8 O historiador Francisco Adolfo de Varnhagen, entretanto, impunha já certo recuo a depoimentos como o de Jean de Léry. Como analisa Cezar (2005, p. 41): Varnhagen "refere-se a Léry como sendo o autor de um importante livro sobre a experiência francesa no Brasil e também como um daqueles viajantes 'amigos da imaginação'. Não há, todavia, nenhum tipo de interdição explícita, apenas uma indicação teórico-metodológica: Léry seria uma fonte sim, porém uma fonte produto de um autor não necessariamente 'objetivo'”.

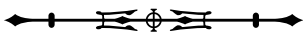


etnólogo. Assim é que trabalhos como "Brasil e Oceania", de Gonçalves Dias, eram realizados somente a partir de textos produzidos por viajantes, cronistas ou por naturalistas. Escrito a partir de uma proposição lançada pelo imperador em 1849, o trabalho deveria comparar os 'selvagens' do Brasil com os da Oceania, investigandoos no tempo antes da colonização para responder quais daqueles povos ofereceriam "maiores probabilidades à empresa da civilização" (apud Pereira, 1943, p. 102-103).

Apesar de os letrados saberem que um dos requisitos ligados ao conhecimento científico deveria pautar-se no conteúdo verossímil do caráter da fonte, dado pelo testemunho ocular, sabiam também que este, por si, não era única garantia de um conhecimento 'verdadeiro' e científico. Esboços de crítica aos diversos estrangeiros que escreveram sobre o Brasil deixando um "imenso fardel de escritos inexatos, insultos, indigestos, absurdos e fabulosos" (Cunha Matos, 1863, p. 123) podem ser encontrados em muitos textos do IHGB. Com efeito, esse foi um dos argumentos fundamentais para que o instituto resolvesse realizar uma expedição somente composta por sábios brasileiros, principalmente após a divulgação do relato de viagem de Francis de La Porte, Conde de Castelneau (1810-1880), publicado em finais da década de 1840 e bastante maledicente em relação ao Brasil (Kury, 2000). Nesse contexto, formouse nos salões da instituição o projeto, encaminhado por Manoel Ferreira Lagos, de realizar uma Comissão Científica de Exploração à província do Ceará. Seria essa a primeira iniciativa dos membros do IHGB de efetivarem estudos in loco não só no campo da etnografia, como em outras áreas científicas, a saber, a geologia, a astronomia, a botânica e a zoologia.

Desde "Brasil e Oceania", escrito entre 1852 e 1853, Gonçalves Dias manifestara a amigos seu interesse em estudar diretamente os índios que conhecera na infância, no Maranhão. A viagem às províncias do Norte, no entanto, só aconteceria anos mais tarde, em 1859, por ocasião da Comissão Científica de Exploração. Organizada pelo Instituto Histórico e financiada pelo governo imperial, a Comissão teve caráter oficial e foi bastante comentada na época por políticos e pela imprensa (Braga, 1962; Porto Alegre, 1989, 2003, 2006; Kury, 2000, 2009). Gonçalves Dias foi o chefe da seção etnográfica e o redator da narrativa de viagem, cujas partes foram publicadas em forma de carta pelo "Jornal do Commercio".

O interesse em estudar etnograficamente a região era justificado pela variedade dos 'tipos' humanos a serem encontrados. Tal interesse partia também da perspectiva de os exploradores encontrarem uma população menos mestiçada com os africanos, como se verificava na região da Corte. Falando da população local, Gonçalves Dias observava que os cearenses representavam "os tipos mais belos e mais caracterizados" da mistura das raças branca e indígena, com pouca presença de negros (Gonçalves Dias, 1924, p. 224). Essa avaliação, reiterada por outro membro da expedição, o botânico Freire Alemão, não deixava de repercutir o ideário indianista que omitia os negros da formação nacional.

Sua estada na província, entretanto, rendeu poucos resultados, uma vez que a Comissão chegara à conclusão de que, entre as populações indígenas remanescentes, não havia quase 'tipos puros' (Porto Alegre, 2003; Kodama, 2009b). Com efeito, esse foi o motivo alegado para que o chefe da seção etnográfica rumasse em direção ao Amazonas para continuar seus trabalhos, quando se dava por finalizada a expedição no Ceará, em 1860.

Ao chegar na província do Amazonas, Gonçalves Dias realizou duas viagens, uma pelo rio Solimões e outra subindo o rio Negro até a fronteira com a Venezuela?. Por ser funcionário do Estado, a primeira excursão de Gonçalves Dias, pelo rio Solimões, tinha por objetivo inspecionar a instrução pública. Visitou as localidades de Coari, Tefé, Fonte Boa, Olivença e Tabatinga. Seu relatório sobre a situação das escolas das freguesias ao longo do rio chama a atenção para a ausência de alunos, a qual se devia à ignorância dos pais que não davam a

9 Da viagem ao rio Negro, restou um caderninho de viagem transcrito e publicado por Lúcia Miguel Pereira em 1943, em sua obra biográfica sobre o poeta, "A vida de Gonçalves Dias". Devido à caligrafia, a autora menciona que teve dificuldades em transcrever todos os nomes das localidades por que passou (Pereira, 1943).

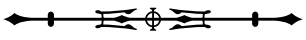


devida importância à escola, levando seus filhos para pescarias por longos períodos. Nota o caso da freguesia de Olivença, na qual o professor da escola, o reverendo Manuel Ferreira Barreto, era também o diretor dos índios. O seu duplo cargo incidia exatamente no papel cumprido pela instrução pública em uma localidade cuja população ainda era, em grande maioria, composta por índios: fazer daquela população futuros cidadãos do Império. É bastante revelador o que diz Gonçalves Dias sobre a importância da instrução pública nessas regiões:

\begin{abstract}
A vantagem da frequência das escolas estaria principalmente em se desabituarem da língua geral que falam sempre, em casa e nas ruas, e em toda parte. Se pouco se demoram nas escolas, se têm essas longas interrupções de quatro meses e mais por ano, é claro que conservarão muitos erros de pronunciação e mesmo de linguagem, sem que isso deva reverter em desfavor do mestre (Gonçalves Dias, 2002, p. 16).
\end{abstract}

Chama a atenção que essa análise, sobre a imposição do ensino da língua portuguesa sobre a língua geral, ou nheengatú, era sustentada ao lado da coleta de vocábulos do tupi para a segunda edição de seu "Dicionário da língua tupi". Enquanto seguia pelo curso dos rios, Gonçalves Dias registrava diversas palavras do nheengatú em um caderno que se mantém preservado em seu arquivo na Biblioteca Nacional, no Rio de Janeiro. Ao mesmo tempo em que cria na importância do tupi para a formação da língua nacional diferenciada do português de Portugal -, sua visão sobre a prioridade do ensino do português correspondia também às políticas traçadas pela 'Instrução Pública' do Estado nesse período, e que deveriam formar, ainda que minimamente, certa homogeneidade dos brasileiros.

A avaliação de Gonçalves Dias sobre a situação do ensino torna evidentes os aspectos contraditórios que envolviam suas ações enquanto agente imperial: por um lado, sua ida ao Amazonas se justificava pela necessidade de se conhecer e inventariar os vestígios de culturas indígenas em vias de desaparecimento. Por outro, o autor do relatório deveria pensar em estratégias de assimilação e de consequente aniquilação dos traços culturais distintivos daquelas populações. Porém, o ato de fazer preservar tais elementos das culturas indígenas, justamente porque se cria inevitável seu desaparecimento, era ele mesmo parte da concepção da etnografia que se constituía em meados do século XIX, e, poderíamos acrescentar, ainda dos estudos antropológicos de grande parte do século seguinte, como os de Roquette-Pinto (Lima et al., 2008).

$\mathrm{Na}$ viagem pelo rio Negro, Gonçalves Dias anotara variados aspectos dos grupos indígenas que encontrara. Ao subir até a região de São Gabriel, observou, por exemplo, a presença de outras línguas que não o tupi entre as povoações do Uaupês, como os Tariana e os Tukano. Ainda sobre as línguas, comentou que os Jahua (Yagua) na fronteira entre Brasil e Peru, que provavelmente encontrara em sua excursão às escolas pelo Solimões, falavam "uma língua tão diferente do Quíchua, como do Tupi" (Gonçalves Dias, 2002, p. 82). Travou conhecimento com os índios Baré, cuja língua de tronco Aruak deixou de ser falada no século XXI (Moore, 2007).

De sua ida à região amazônica, restaram diversos objetos etnográficos dos Tuxaua, dos Arara, dos Tukano, dos Munduruku, dos Jahua (Yagua). Enviados para o Rio de Janeiro para a Exposição Nacional ocorrida em 1861, esses objetos posteriormente fizeram parte da Exposição Antropológica, em 1882 (Castro Faria, 1949), e foram incorporados às coleções do Museu Nacional, que Roquette-Pinto e Raimundo Lopes muito bem conheceram. Algumas das peças foram retratadas em estampas litográficas feitas pelos irmãos Fleiuss (Figura 1), juntamente com outros produtos coletados pela Comissão Cientíica de Exploração. Infelizmente, as estampas permaneceram sem identificação. Apesar de Gonçalves Dias ter enviado de Manaus um relatório contendo uma listagem descritiva do que estava sendo remetido, as reproduções feitas por Fleuiss Irmãos e Linde não fazem menção à origem étnica dos artefatos. A identificação da etnia referente à imagem da Figura 1 como sendo do povo Yágua só me foi possível recentemente, quando cotejei a lista de Gonçalves Dias e a descrição do objeto com a imagem litográfica. Essa tarefa, de nomear as imagens, não foi feita pelo próprio etnógrafopoeta. Aparentemente, Gonçalves Dias, que já se encontrava doente e em tratamento na Europa quando eram preparadas 


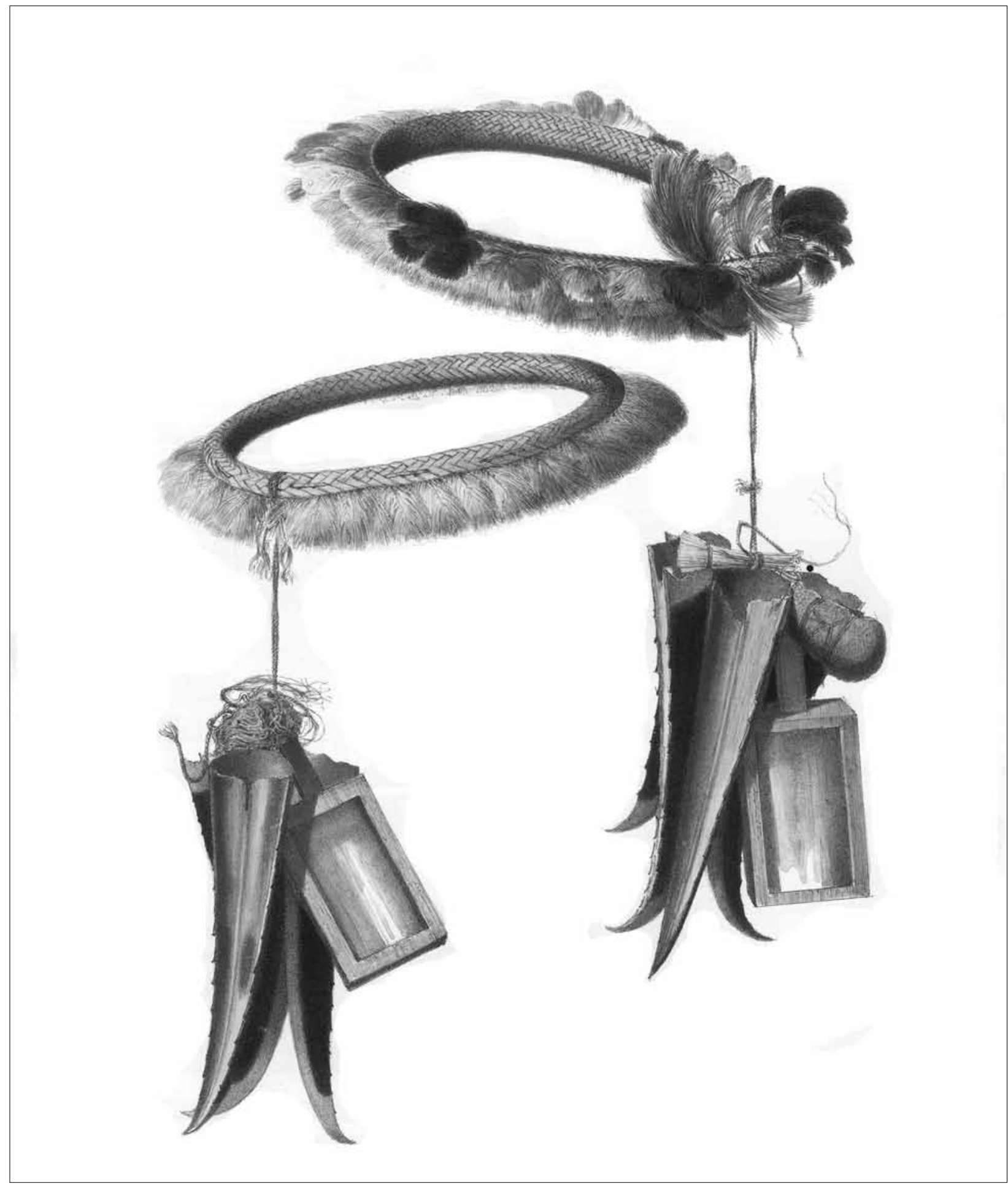

Figura1. Litografia de Fleiuss Irmãos e Linde. Acangatar (adorno em forma de anel para cabeça) com espelhos e bico de tucanos dos "Jaúás" (Yaguas), segundo Gonçalves Dias. Esse grupo ainda habita a região de Loreto, no Peru. Acervo da Seção de Iconografia da Biblioteca Nacional, ARM 20.2.5.

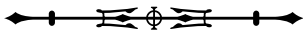


as litogravuras, não pôde ou não teve tempo de identificar as peças retratadas ${ }^{10}$. A riqueza e a diversidade daqueles povos, somente vislumbradas nos registros parciais deixados, ainda teriam de esperar muito tempo para novamente serem revistas, já com outros olhos, sob outras histórias.

\section{CONSIDERAÇÕES FINAIS}

Ao retomarmos alguns dos escritos etnográficos do IHGB e a viagem de Gonçalves Dias no contexto da Comissão Científica, é possível identificar algumas ambiguidades do modelo da etnografia do período, que tinha como pressuposto a necessária 'invisibilização' dos grupos indígenas. Uma vez que o modelo histórico de concepção da nação se colocava no centro do projeto de construção do Estado imperial, a etnografia ganhava relevo como um campo de estudos legitimado ao fornecer o conhecimento sobre aqueles que seriam os 'primitivos habitantes' do país. Mesmo o estatuto desse conhecimento, como corolário de um discurso histórico pragmático e civilizador, restringia a capacidade de conhecer seu próprio objeto. É nesse sentido que podemos entender a relativa falta de interesse dos letrados do instituto pelos grupos não tupi. Relativa porque, em grande parte, a manutenção da divisão básica Tupi/Tapuia está relacionada à escassez de informações mais especializadas sobre a diversidade linguística dos grupos não tupi. Os estudos disponíveis sobre os grupos sul-americanos naquele momento eram os de d'Orbigny, Wied-Neuwied e Martius. Como comentamos, não obstante Martius ter primeiramente reconhecido e denominado o tronco Jê, reiterou a valorização da língua geral derivada do tupi em seu "Glossaria Linguarum", publicado na década de 1860.

Gonçalves Dias, em "Brasil e Oceania”, não contestou a divisão bipolar para tratar dos índios do Brasil. Mas procurou ser cauteloso ao tratar dos 'tapuias', não afirmando qualquer identidade característica dos diferentes grupos 'tapuias' e se limitando a repetir o que diziam os cronistas coloniais, de que falavam 'dialetos' ou línguas diversíssimas entre si. Gonçalves
Dias acreditou, até certo ponto, na 'decadência' sofrida pelos indígenas, tanto tapuias como tupis, mas salientou que o fato de ocuparem um grau civilizatório inferior aos europeus devia-se, sobretudo, à ação dos últimos.

Nesse mesmo estudo que apresentou ao imperador, enfatizou que mais do que os povos da Oceania, os índios do Brasil - tanto tupis como tapuias - teriam melhores condições de serem civilizados, por serem superiores a eles, tanto no "físico como nas faculdades morais e intelectuais" (Gonçalves Dias, 1867, p. 395). O poeta-etnógrafo, sem dúvida, privilegiou o tupi, como afirmaram Raimundo Lopes e Roquette-Pinto, e podemos compreender tal valorização no próprio sentido da etnografia de seu contexto. Privilegiou, ainda, a ideia do índio 'puro', que não pôde encontrar no Ceará, onde, mesmo assim, travou contato com alguns Xocó e outros índios da região do Cariri que estavam em convívio e em conflito, desde os tempos coloniais, com a civilização branca. Apesar dessas restrições impostas por aquela etnografia, Gonçalves Dias não compartilhou de todo a visão negativa que estava implicada na percepção bipolar tupi-tapuia, procurando atentar para os legados positivos indígenas que ainda estariam presentes no brasileiro comum.

Contudo, os grupos distintos que encontrou não foram analisados em um estudo etnográfico pelo autor, já doente quando retornou da expedição para ir se tratar na Europa. Uma síntese da viagem às províncias do Norte nunca chegou a ser escrita. Parte do material que Gonçalves Dias coletou e que figurou na Exposição Nacional da Indústria, em 1861, talvez caracterize bem o que pregou a etnografia do IHGB em suas primeiras décadas. Na figura intitulada "Tropheo das Armas dos Indigenas do Amazonas” (Figura 2), vê-se como se reproduzia o olhar que tornava invisível a variedade dos grupos indígenas. Aimagem, que parece enaltecer unicamente o caráter guerreiro dos índios, transformava em peça única diferentes artefatos, cujas procedências étnicas pouco importavam em si mesmas.

\footnotetext{
10 As peças foram reunidas por 'tipos' e não por 'tribos', como conta Guilherme Schuch Capanema a Gonçalves Dias em carta de 8 de dezembro de 1862 (Gonçalves Dias, 1971, p. 276).
}

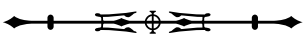




\section{PRIMEIRA অXPOSIÇĀO NACIONAL BRASILEIRA EM 1861}

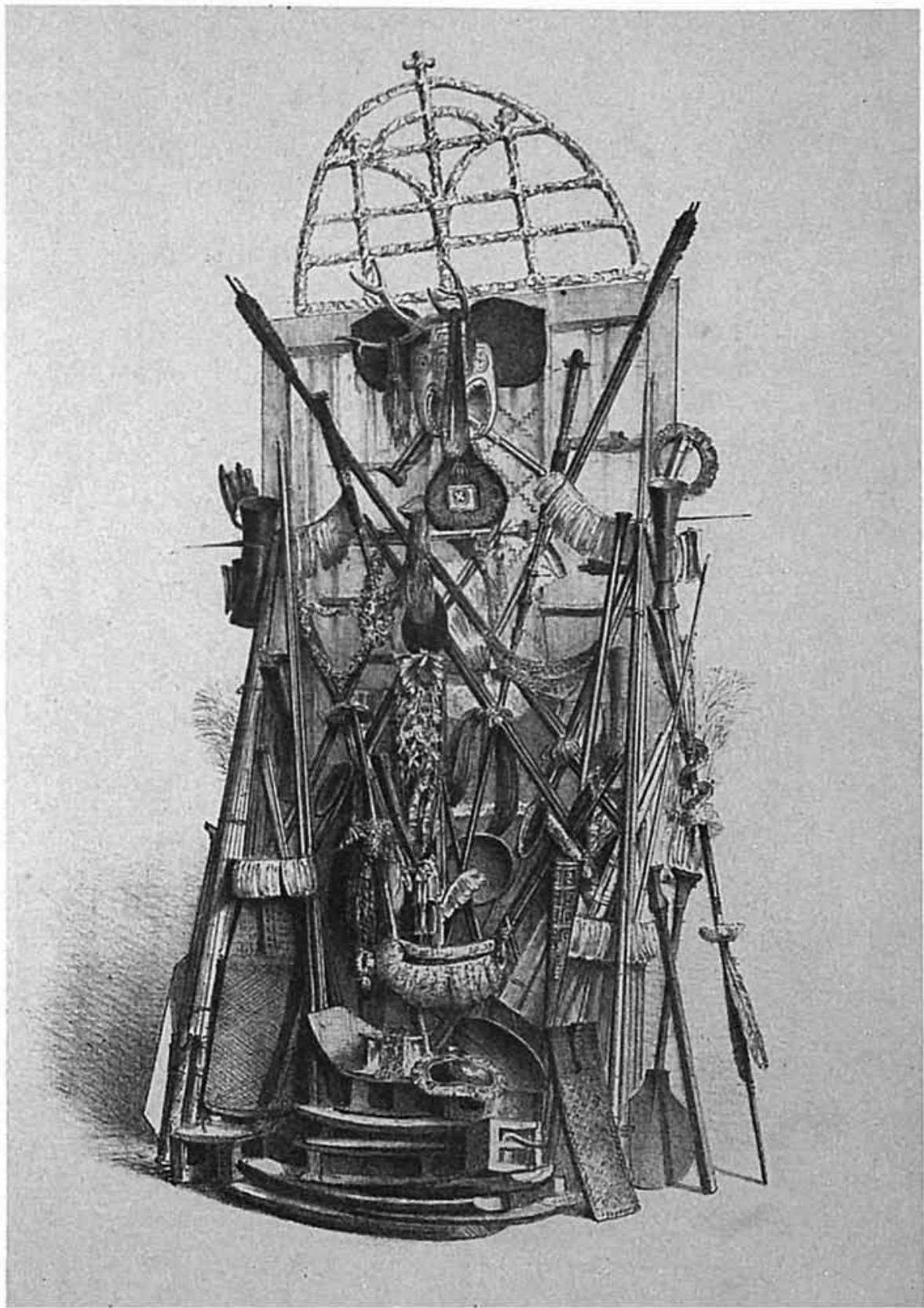

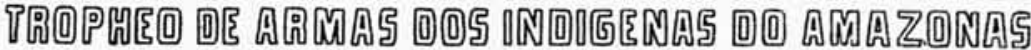

Figura 2. "Tropheo de Armas dos Indigenas do Amazonas" (Recordações..., 1862).

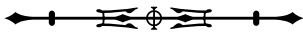




\section{AGRADECIMENTOS}

Agradeço à Lorelai Kury por indicações bibliográficas sobre a Comissão Científica de Exploração.

\section{REFERÊNCIAS}

178 a . Sessão em 16 de Setembro de 1847. Revista do Instituto Historico e Geographico do Brazil, Rio de Janeiro, t. 9, v. 2, p. 442-444, 1847.

ABREU, João Capistrano. Os Guaianases de Piratininga. In: ABREU, João Capistrano de. Caminhos antigos e povoamento do Brasil. Belo Horizonte: Itatiaia; São Paulo: EDUSP, 1989. p. 24-28.

ALMEIDA, Maria Regina Celestino. O lugar dos índios na história entre múltiplos usos do passado: reflexões sobre cultura histórica e cultura política. In: SOIHET, R.; ALMEIDA, M. R. C.; AZEVEDO, C.; GONTIJO, R. (Orgs.). Mitos, projetos e práticas políticas: memória e historiografia. Rio de Janeiro: Civilização Brasileira, 2009. p. 207-230.

AMADO, Janaína. Diogo Álvares, o Caramuru e a fundação mítica do Brasil. Estudos Históricos, v. 14, n. 25, 2000. Disponível em: <wmw.cpdoc.fgv.br/revista/arq/282.pdf>. Acesso em: 20 mar. 2006.

AMADO, Janaína. Região, sertão, nação. Estudos Históricos, Rio de Janeiro, v. 8, n. 15, p. 145-152, 1995.

AMOROSO, Marta R. Capistrano de Abreu e os índios. In: REIS, Elisa; ALMEIDA, Maria Hermínia Tavares de; FRY, Peter (Orgs.). Política e cultura: visões do passado e perspectivas contemporâneas. São Paulo: Hucitec, 1996. p. 182-196.

ARAÚJO, Valdei Lopes. A experiência do tempo. Conceitos e narrativas na formação nacional brasileira (1813-1845). São Paulo: Hucitec, 2008.

ARTIGO Extrahido do "Panorama". Revista do Instituto Histórico e Geográfico Brasileiro, Rio de Janeiro, t. 7, p. 499-507, 1845.

BRAGA, Renato. História da Comissão Científica de Exploração. Fortaleza: Imprensa Universitária do Ceará, 1962.

CÂNDIDO, Antonio. Formação da literatura brasileira: momentos decisivos. 7. ed. Belo Horizonte: Itatiaia, 1993. v. 2.

CASTRO FARIA, Luiz de. As exposições de antropologia e arqueologia do Museu Nacional. Rio de Janeiro: Imprensa Nacional, Ministério da Educação e Saúde, Museu Nacional, 1949.

CERQUEIRA E SILVA, Ignácio Accioli de. Dissertação historica, ethnographica e política. Revista do Instituto Histórico e Geográfico Brasileiro, Rio de Janeiro, t. 12, p. 143-257, 1849.

CERTEAU, Michel de. A escrita da História. Rio de Janeiro: Forense Universitária, 1982.
CEZAR, Temístocles. Anciens, modernes et sauvages et l'écriture de l'histoire du Brésil au XIXe siècle. Le cas de l'origine des tupi. Anabases. Traditions et réceptions de l'Antiquité, v. 8, p. 43-65, 2008.

CEZAR, Temístocles. Thevet e Léry: visão, crença e história no Brasil do século XVI. Ensaio sobre historiografia e relatos de viagem. Ciências \& Letras, n. 37, p. 25-43, jan.-jun. 2005.

CEZAR, Temístocles. Presentismo, memória e poesia. Noções da escrita da História no Brasil oitocentista. In: PESAVENTO, Sandra Jatahy (Org.). Escrita, linguagem, objetos. Leituras de História cultural. Bauru: EDUSC, 2004. p. 43-80.

CEZAR, Temístocles. Como deveria ser escrita a história do Brasil no século XIX. Ensaio de história intelectual. In: PESAVENTO, Sandra J. (Org.). História cultural: experiências de pesquisa. Porto Alegre: Editora da UFRGS, 2003. p. 173-208.

CHRISTINO, Beatriz Protti. A rede de Capistrano de Abreu (18531927): uma análise historiográfica do Ra-txa Hu-ni-ku-ĩ em face da sul-americanística dos anos 1890-1929. 2007. Tese (Doutorado em Linguística) - Universidade de São Paulo, São Paulo, 2007.

CHRISTINO, Beatriz Protti; CRUZ, Aline. O contato linguístico para Martius (1794-1868), Steinen (1855-1929) e Ehrenreich (1855-1914). Papia, Brasília, n. 15, p. 102-110, 2005.

CLIFFORD, James. Sobre a autoridade etnográfica. In: GONÇALVES, José Reginaldo Santos (Org.). A experiência etnográfica: antropologia e literatura no século $X X$. Rio de Janeiro: Editora UFRJ, 1998. p. 17-62.

CUNHA, Manuela Carneiro. Les Études Gé. L’Homme, v. 33, n. 126-128, p. 77-93, abr.-dez. 1993.

CUNHA, Manuela Carneiro. Política indigenista no século XIX. In: CUNHA, Manuela Carneiro (Org.). História dos índios no Brasil. São Paulo: Companhia das Letras, Secretaria Municipal de Cultura, FAPESP, 1992a. p. 133-154.

CUNHA, Manuela Carneiro (Org.). Legislação indigenista no século XIX. Uma Compilação (1808-1889). São Paulo: Comissão Pró-Índio de São Paulo/EDUSP, 1992 b.

CUNHA BARBOSA, Januário. Qual seria hoje o melhor sistema de colonizar os índios entranhados em nossos sertões. Revista do Instituto Histórico e Geográfico Brasileiro, Rio de Janeiro, t. 2, p. 3-18, 1916 [1840].

CUNHA BARBOSA, Januário. Programa: se a introdução dos escravos africanos no Brazil embaraça a civilisação dos nossos indigenas. Revista do Instituto Histórico e Geográfico Brasileiro, Rio de Janeiro, t. 1, p. 123-129, 1908 [1839].

CUNHA MATOS, Raimundo José da. Dissertação acerca do Sistema de Escrever a História Antiga e Moderna do Brasil. Revista do Instituto Histórico e Geográfico Brasileiro, t. 26, p. 121-143, 1863 [1838?].

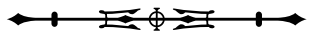


DENIS, Ferdinand. Brésil. [tomo Colombie et Guyanes da coleção "L'Univers. Histoire et Description de Tous les Peuples", dirigida por M. C. Famin]. Paris: Firmin Didot Frères, 1838.

DIAS, Maria Odila da Silva. Aspectos da Ilustração no Brasil. Revista do Instituto Histórico e Geográfico Brasileiro, Rio de Janeiro, v. 278, p. 105-170, 1968.

FIGUEIRÔA, Silvia. Associativismo científico no Brasil: o Instituto Histórico e Geográfico Brasileiro como espaço institucional para as ciências naturais durante o século XIX. In: LAFUENTE, A.; ORTEGA, Elena y M. L. (Orgs.). Mundialización de la ciência y cultura nacional. Actas Del Congreso Internacional "Ciência, descubrimiento y mundo colonial". Aranjuez (Madrid): Ediciones Doce Calles, 1993. p. 449-459.

FRANÇA, José Feliciano. Apontamentos sobre a vida do Índio Guido Pokrane e sobre o Francez Guido Marlière. Revista do Instituto Histórico e Geográfico Brasileiro, Rio de Janeiro, t. 18, p. $426-434,1855$.

GONÇALVES DIAS, Antônio. Gonçalves Dias na Amazônia. Introdução de Josué Montello. Rio de Janeiro: Academia Brasileira de Letras, 2002.

GONÇALVES DIAS, Antônio. Dicionário da Língua Tupi chamada Língua-geral dos Indígenas do Brasil. In: GONÇALVES DIAS, Antônio. Poesia e prosa completas. Rio de Janeiro: Nova Aguilar, 1998. p. 1147-1224.

GONÇALVES DIAS, Antônio. Correspondência passiva de Antonio Gonçalves Dias. Anais da Biblioteca Nacional, Rio de Janeiro, v. 91, p. 11-371, 1971.

GONÇALVES DIAS, Antônio. Cartas enviadas ao Jornal do Commercio do Rio, por Gonçalves Dias durante sua estadia no Ceará como membro da Commissão Científica. Revista Trimensal do Instituto do Ceará, t. 38, p. 213-230, 1924.

GONÇALVES DIAS, Antônio. Brasil e Oceania. Revista Trimensal do Instituto Historico, Geographico e Ethnographico do Brasil, t. 30 (parte 2), p. 5-192; 257-396, 1867.

GONTIJO, Rebeca. Na trilha de Capistrano de Abreu (1853-1927): índios, história e formação do Brasil. 2009. Tese (Doutorado em História) - Universidade Federal Fluminense, Niterói, 2009.

GUIMARÃES, Lúcia P. Um olhar sobre o continente: o Instituto Histórico e Geográfico Brasileiro e o Congresso Internacional de História da América. Estudos Históricos, Rio de Janeiro, v. 10, n. 20, p. 217-229, 1997.

GUIMARÃES, Lúcia P. Debaixo da imediata proteção de sua majestade imperial: o Instituto Histórico e Geográfico Brasileiro (1838-1889). Revista do Instituto Histórico e Geográfico Brasileiro, Rio de Janeiro, v. 156, n. 388, p. 459-613, jul.-set. 1995.
GUIMARÃES, Manoel L. S. A disputa pelo passado na cultura histórica oitocentista no Brasil. In: CARVALHO, José Murilo (Org.). Nação e cidadania no Império: novos horizontes. Rio de Janeiro: Civilização Brasileira, 2007. p. 93-122.

GUIMARÃES, Manoel L. S. A cultura histórica oitocentista: a constituição de uma memória disciplinar. In: PESAVENTO, Sandra (Org.). História cultural: experiências de pesquisa. Porto Alegre: Editora da UFRGS, 2003. p. 9-36.

GUIMARÃES, Manoel L. S. Reinventando a tradição: sobre antiquariado e a escrita da história. Humanas - Revista do Instituto de Filosofia e Ciências Humanas, v. 23, n. 1-2, p. 111-143, 2000.

GUIMARÃES, Manoel L. S. Nação e civilização nos trópicos: o Instituto Histórico e Geográfico Brasileiro e o projeto de uma história nacional. Estudos Históricos, v. 1, p. 5-27, 1988.

HARTOG, François. Anciens, Modernes, Sauvages. Paris: Galaade Éditions, 2005.

HARTOG, François. Régimes d'historicité. Présentisme et expériences du temps. Paris: Seuil, 2003.

HARTOG, François. O Espelho de Heródoto. Belo Horizonte: Editora UFMG, 2001.

KODAMA, Kaori. Os índios no Império do Brasil: a etnografia do IHGB entre as décadas de 1840 e 1860. Rio de Janeiro: Editora Fiocruz; São Paulo: EDUSP, 2009a.

KODAMA, Kaori. Em busca da gênese do Brasil nas províncias do Norte: Gonçalves Dias e os trabalhos etnográficos da Comissão Científica de Exploração. In: KURY, Lorelai (Org.). Comissão Científica do Império (1859-1861). Rio de Janeiro: Andrea Jacobsson Estúdio, 2009b. p. 115-153.

KURY, Lorelai. Explorar o Brasil: o Império, as ciências e a nação. In: KURY, Lorelai (Org.). Comissão Científica do Império (18591861). Rio de Janeiro: Andrea Jacobsson Estúdio, 2009. p. 19-49.

KURY, Lorelai. A Comissão Científica de Exploração (1859-1861). In: HEIZER, A.; VIDEIRA, A. A. P. (Orgs.). Ciência, civilização e império nos Trópicos. Rio de Janeiro: Access, 2000. p. 29-54.

LIMA, Nísia Trindade. Um sertão chamado Brasil: intelectuais e representação geográfica da identidade nacional. Rio de Janeiro: Revan/IUPERJ, 1999.

LIMA, Nísia Trindade; SANTOS, Ricardo Ventura; COIMBRA JR., Carlos E. A. Rondônia de Edgard Roquette-Pinto. In: LIMA, Nísia Trindade; SÁ, Dominichi Miranda de (Orgs.). Antropologia brasiliana: ciência e educação na obra de Edgard Roquette-Pinto. Belo Horizonte: UFMG; Rio de Janeiro: Fiocruz, 2008. p. 99-121.

LISBOA, Karen M. A nova Atlântida de Spix e Martius: natureza e civilização na viagem pelo Brasil (1817-1820). São Paulo: Hucitec, Fapesp, 1997.

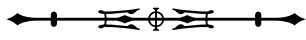


LOPES, Raimundo. Gonçalves Dias e a raça americana. Revista do Instituto Histórico e Geográfico Brasileiro, Rio de Janeiro, v. 2, p. 572-618, 1933.

MACHADO DE OLIVEIRA, José Joaquim. Os Cayapós. Revista do Instituto Histórico e Geográfico Brasileiro, t. 24, p. 491-524, 1973a [1861].

MACHADO DE OLIVEIRA, José Joaquim. A celebração da Paixão de Jesus Christo entre os Guaranys. Revista do Instituto Histórico e Geográfico Brasileiro, t. 4, p. 331-349, 1973b [1840].

MACHADO DE OLIVEIRA, José Joaquim. Falla com que o Exmo. Presidente da Provincia do Espirito Santo, José Joaquim Machado de Oliveira abriu a Assemblea Legislativa Provincial, no dia $1^{\circ} \mathrm{de}$ abril de 1841. Rio de Janeiro: Typographia Nacional, 1841.

MARTIUS, Karl Friedrich Philipp von. $O$ passado e o futuro do homem americano. Revista do Instituto Histórico e Geográfico de São Paulo, v. 9, p. 534-562, 1904.

MARTIUS, Karl Friedrich Philipp von. Glossaria Linguarum Brasiliensium. Erlangen: Druck von Junge \& Sohn, 1863.

MATTOS, Ilmar Rohloff de. Construtores e herdeiros: a trama dos interesses na construção da unidade política. In: JANCSÒ, I. (Org.). Independência: história e historiografia. São Paulo: Hucitec, 2005. p. 271-300.

MATTOS, Ilmar Rohloff de. Do Império do Brasil ao Império do Brasil. In: FACULDADE DE LETRAS DA UNIVERSIDADE DO PORTO (Org.). Estudos em homenagem a Luís Antonio de Oliveira Ramos. Porto: Universidade do Porto, 2004. v. 2, p. 727-736

MATTOS, Ilmar Rohloff de. O Tempo Saquarema. Rio de Janeiro: Access, 1994

MATTOS, Selma Rinaldi de. Para formar os brasileiros. $\bigcirc$ Compêndio para a História do Brasil de Abreu e Lima e a expansão para dentro do Império do Brasil. 2007. Tese (Doutorado em História) - Universidade de São Paulo, São Paulo, 2007.

MONTEIRO, John M. Tupis, Tapuias e Historiadores: estudos de história indígena e do indigenismo. 2001. Tese (Livre-Docência em Antropologia) - Universidade de Campinas, Campinas, 2001. Disponível em: <http://www.ifch.unicamp.br/ihb/estudos/TupiTapuia. pdf $>$. Acesso em: 13 jul. 2005.

MONTEIRO, John M. As 'raças' indígenas no pensamento brasileiro do Império. In: MAIO, Marcos Chor; SANTOS, Ricardo Ventura (Orgs.). Raça, ciência e sociedade. Rio de Janeiro: Editora Fiocruz, Centro Cultural Banco do Brasil, 1996. p. 15-21.

MOORE, Denny. Línguas indígenas: situação atual. Patrimônio-Revista eletrônica do IPHAN, n. 6, jan.-fev. 2007. Disponível em: <http:// www.labjor.unicamp.br/patrimonio/secao. php? id $=1 \& d s=20>$. Acesso em: 19 jan. 2010
MOREL, Marcos. O mau selvagem: índios invisíveis no Romantismo brasileiro. In: LESSA, Mônica Leite; FONSECA, Silvia Carla Pereira de Brito (Orgs.). Entre a Monarquia e a República: imprensa, pensamento político e historiografia (1822-1889). Rio de Janeiro: EDUERJ, 2008. p. 123-145.

NOVOS ESTATUDOS DO INSTITUTO HISTÓRICO E GEOGRÁFICO BRASILEIRO. Rio de Janeiro: Ed. Paula Britto, 1851.

OLIVEIRA, Laura Nogueira. Os Índios Bravos e o Sr. Visconde: os indígenas brasileiros na obra de Francisco Adolfo de Varnhagen. 2000. Dissertação (Mestrado em História) - Universidade Federal de Minas Gerais, Belo Horizonte, 2000

OLIVEIRA, Lúcia Lippi. A conquista do espaço: sertão e fronteira no pensamento brasileiro. História, Ciência, Saúde - Manguinhos, v. 5 (suplemento), p. 195-215, 1998.

OLIVEIRA, Maria da Glória de. Escrever vidas, narrar a história. A biografia como problema historiográfico no Brasil oitocentista. 2009. Tese (Doutorado em História) - Universidade Federal do Rio de Janeiro, Rio de Janeiro, 2009.

OTONI, Teófilo. Notícia sobre os selvagens do Mucuri. Organização de Regina Horta Duarte. Belo Horizonte: Editora UFMG, 2002.

PEREIRA, Lúcia Miguel. A vida de Gonçalves Dias. Rio de Janeiro: José Olympio, 1943

PORTO ALEGRE, Maria Sylvia. Os ziguezagues do dr. Capanema - ciência, cultura e política no século XIX. Fortaleza: Museu do Ceará, Secretaria da Cultura do Estado do Ceará, 2006.

PORTO ALEGRE, Maria Sylvia. Comissão das Borboletas. A Ciência do Império entre o Ceará e a Corte. Fortaleza: Museu de Ceará, Expressão Gráfica, 2003

PORTO ALEGRE, Maria Sylvia. O Brasil descobre os sertões. A expedição científica de 1859 ao Ceará. São Paulo: Vértice/ANPOCS, 1989.

PUNTONI, Pedro. O Sr. Varnhagen e o patriotismo caboclo: o indígena e o indianismo perante a historiografia brasileira. In: JANCSÒ, István (Org.). Brasil: Formação do Estado e da Nação. São Paulo: Fapesp, Hucitec; Ijuí: Editora Unijuí, 2003. p. 633-675.

RECORDAÇÕES da Exposição Nacional Brasileira em 1861. Rio de Janeiro: Typographia Universal de Laemmert, 1862.

RODRIGUES, José Honório. Teoria da História do Brasil: introdução metodológica. 4. ed. São Paulo: Cia Editora Nacional, 1978.

ROQUETTE-PINTO, Edgard. Rondonia: anthropologia-ethnographia. 7. ed. Rio de Janeiro: FIOCRUZ, 2005.

ROQUETTE-PINTO, Edgard. Gonçalves Dias e os índios. In: Gonçalves Dias. Conferências realizadas na Academia Brasileira. Rio de Janeiro: ABL, 1948. p. 83-93.

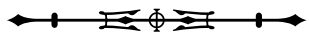


SOUZA E SILVA, Joaquim Norberto de. Memoria historica e documentada das aldêas de indios da Provincia do Rio de Janeiro. Revista do Instituto Histórico e Geográfico Brasileiro, v. 17, p. 109-263, 1973 [1854].

STOCKING JR., George W. The ethnographer's magic: fieldwork in British Anthropology from Tylor to Malinowski. In: STOCKING JR., George W. (Ed.). Observers observed: essays on Ethnographic Fieldwork. LondonMisconsin: University of Wisconsin Press, 1983. p. $70-120$.

SUSSEKIND, Flora. O escritor como genealogista. In: PIZARRO, Ana (Org.). América Latina: palavra, literatura e cultura. Campinas: Unicamp, 1994. v. 2, p. 451-485.

TREECE, David. Exilados, aliados, rebeldes: o movimento indianista, a política indigenista e o Estado-Nação imperial. Traduçao de Fábio Fonseca de Melo. São Paulo: Nankin/EDUSP, 2008.
TURIN, Rodrigo. Tempos cruzados: escrita etnográfica e tempo histórico no Brasil oitocentista. Tese (Doutorado em História) Universidade Federal do Rio de Janeiro, Rio de Janeiro, 2009.

VARNHAGEN, Francisco Adolfo de. Varnhagen. [Introdução e organização de Nilo Odália/Coordenação de Florestan Fernandes]. São Paulo: Ática, 1979. (Coleção Grandes Cientistas Sociais).

VARNHAGEN, Francisco Adolfo de. Memória sobre a necessidade do estudo e ensino das línguas indígenas do Brasil. Revista do Instituto Histórico e Geográfico Brasileiro, Rio de Janeiro, t. 3, p. 53-63, 1842.

WEHLING, A. As origens do Instituto Histórico e Geográfico Brasileiro. Revista do Instituto Histórico e Geográfico Brasileiro, v. 338, p. 7-16, 1983.

Recebido: 03/02/2010

Aprovado: 02/08/2010 